\title{
Bone oedema like lesion of the second phalanx causing a non-weight bearing lameness in a 4 years old Trakehnen mare
}

\author{
Martin-J. Helweg', Sabine Metzemacher', Thorben Schulze', Lena Kottmeier ${ }^{2}$ and Maren Hellige² \\ 1 Pferdeklinik Burg Müggenhausen \\ 2 Tierarztpraxis Beihsner, Ebergötzen \\ 3 Klinik für Pferde, Stiftung Tierärztliche Hochschule Hannover
}

\begin{abstract}
Summary: Bone marrow oedema like lesions (BMELLs) are described in both human athletes and sport horses. Most commonly runners and track and field athletes are affected. BMELLs are described in young military recruits at the beginning of their training, too. While all kinds of sport horses are affected, BMELLs are described most commonly in racehorses. Like in humans the bones of the distal limb are affected the most. BMELLs in the horse are described for the navicular bone, the middle phalanx and the metacarpal and metatarsal bone. The diagnosis is based on scintigraphical and MRI findings. In humans, the treatment depends on the severity of clinical, radiological and MR findings. Rest and reduced training is part of every treatment regime. Surgical treatment like bone drilling is described for severe cases. A correlation between BMELLs and osteoarthritis is discussed. This article describes a young dressage horse with a non-weight bearing lameness of sudden onset. Because clinical and radiological findings did not explain the lameness conclusively the horse underwent low field MR imaging $(0,27 T)$. On STIR images in sagittal and frontal planes a hyperintense focus with a hypointense rim was seen in the bone marrow in the dorsomedial part of the second phalanx. A corresponding hypointense focus was seen on T2*-weighted gradient echo sequences. On T2-weighted spin echo sequences the bone marrow appeared normal. The horse was treated with a Robert Jones bandage, NSAIDs for 14 days, disodium clodronate for ten days and box rest over a period of eight weeks. After that, the horse was walked at hand for four weeks. Fourteen weeks after the sudden onset of the lameness the horse was sound and started light dressage work.
\end{abstract}

Keywords: MRI / horse / bone oedema like lesions / lameness / orthopaedics / diagnostic imaging

Citation: Helweg M.-J., Metzemacher S., Schulze T., Kottmeier L., Hellige M. (2014) Bone oedema like lesion of the second phalanx causing a non-weight bearing lameness in a 4 years old Trakehnen mare - A case report. Pferdeheilkunde 30, 165-170

Correspondence: Martin Helweg, Pferdeklinik Burg Müggenhausen, Heimerzheimer Strasse 18, 53919 Weilerswist, Germany, E-Mail: helweg.martin@gmail.com

\section{Introduction}

If a sudden, severe lameness occurs, the following diseases must be considered in the differential diagnosis: fracture or fissure of a limb bone, pododermatitis circumscripta septica and joint or tendon dislocation (Ross and Dyson 2005). Also, a unilateral laminitis should be taken into account.

This case report describes an acute, severe, non-weight bearing lameness of the left front limb in a four-year old Trakehner mare that was kept on the pasture after six weeks of initial training. The usual imaging techniques (radiography, ultrasonography) did not indicate the cause of the pain. MRI examination of the distal toe of the left forelimb revealed oedema like findings in the short pastern bone. The indication of the cause of lameness and the diagnosis were solely based on MRI findings in the present case.

\section{Literature}

Magnetic resonance imaging is the only technique that allows a reliable diagnosis of bone oedema like lesions. They belong to a disease complex referred to in the English literature as bone marrow lesions (Olive et al. 2010). In equine medicine, only a few case reports exist that describe bone oedema like lesions of the short pastern or the navicular bone as the cause of lameness (Dyson et al. 2005, Olive et al. 2010, Janssen et al. 2011). Both in human and in equine medicine, the clinical significance of bone oedema like lesions is not yet conclusively resolved. They occur in individuals both, with and without clinical findings (Kiuru 2005, Olive et al. 2010, Werpy 2010) and the underlying aetiology is still not fully understood. In the literature, three different aetiologies are discussed. First, an initial trauma to the bone and surrounding soft tissue in terms of compression and strain is assumed as a cause. Other authors see a physical strain to the bone that is beyond its adaptability to be causal. At last, a disorder of bone metabolism with regard to the fine hormonal modulation is considered a possible aetiology (Kiuru 2005).

Due to the still unclear aetiology and the lack of experience with this disease in equine orthopaedics and its correlation to human medicine, the treatment of such bone oedema like lesions is difficult. However, there is, consistent in all therapeutic approaches, the reference to a significant reduction of physical strain without complete immobilization. As to the medication in horses, the use of bisphosphonates is described (Bathe 2011 , Janssen et al. 2011).

In the veterinary literature, the prognosis quo ad restitutio et integrum is indicated as bad, but it must be noted that the assessment is based on the results of only few case reports. 


\section{Medical history}

A four-year-old Trakehner mare showed a severe lameness of the left forelimb after six weeks of initial training and a subsequent two-day stay on pasture. On clinical examination by the referring practitioner a slightly painful swelling was found dorsomedial to the coronary band that was not warm to the touch. Also a slight pulsation of the Aa. digitales lateralis et medialis was detected. The horse was negative to examination with hoof testers. Since a fracture was suspected, lateromedial and dorsopalmar radiographs as well as a dorso 65 degree proximal-palmarodistal oblique projection (Oxspring) of the left distal forelimb were taken by the referring veterinarian. However, none of the radiological findings could explain either the lameness itself or its degree. The horse was stabled and a distal limb bandage as well as a foot soak bandage was put on. Twice daily it was given oral non-steroidal antiinflammatory drugs by the owner. The lameness hardly improved under this treatment during the following days. Four days after the onset of the lameness the mare therefore was admitted to the equine hospital.

Results of the physical examination and the clinical orthopaedic examination

On admission to the hospital, the mare showed a significantly reduced general condition and a severe lameness of the left forelimb. Picking up the contralateral limb was not possible. A slight pulsation of the Aa. digitales lateralis et medialis was palpable at the level of the proximal sesamoid bones. In the area of the coronary band, there was an approximately $1.5 \mathrm{~cm}$ high swelling going from the dorsal midline to the heel region. On palpation this swelling was slightly painful and warm, of firm consistency and not displaceable. The examination with hoof testers was negative.

\section{Results of the radiographic examination}

Images were taken in lateromedial, dorsopalmar, dorsolateral-palmaromedial, dorsomedial-palmarolateral and in a dorso 65 degree proximal-palmarodistal oblique projection (Oxspring). Here the soft tissue swelling seen in the area of the coronary band during the clinical examination could also be traced (Fig. 1). Again, however, no radiographic findings were made that indicated such a degree of lameness. Since a cause of the lameness was detected by neither the clinical nor radiological examination, magnetic resonance imaging was undertaken in the sedated, standing horse.
In preparation for the MR imaging examination, the mare was sedated with romifidine $0.08 \mathrm{mg} / \mathrm{kg}$ iv $\left(\right.$ Sedivet ${ }^{\circledR}$, Boehringer Ingelheim) and a conduction anaesthesia of the $\mathrm{Nn}$. palmares digitales lateralis et medialis was performed with $6 \mathrm{ml}$ of $2 \%$ mepivacaine hydrochloride solution (Scandicaine ${ }^{\circledR}$, AstraZeneca) at the level of the proximal sesamoid bones (abaxial sesamoid nerve block). Afterwards, the mare loaded the limb well when at a walking pace. The MRI examination (Equine Distal Limb Scanner, Hallmarq Veterinary Imaging Ltd.) contained the following sequences: (Table 1)

\section{Results of the MRI examination}

The MRI images were analysed with the dicomPACS ${ }^{\circledR}$ vet software (OR Technology, Rostock, Germany). They were evaluated on a plasma screen (NEC MultiSync MD301C4, NEC, Munich, Germany).

The following results could be obtained: On the sagittal STIR recording a focal hyperintense area extending from the subchondral bone into the medullary bone showed. On one of the STIR-weighted sequences a disrupted line of the articular cartilage could be seen (Fig. 2). Also, a moderate effusion of the recessus dorsalis and palmaris of the coffin joint was detected on these images. On T2-weighted gradient echo sequences in both dorsal and transverse orientation a focal, hypointense area with a very hypointense rim area (Fig. 3 and 4)

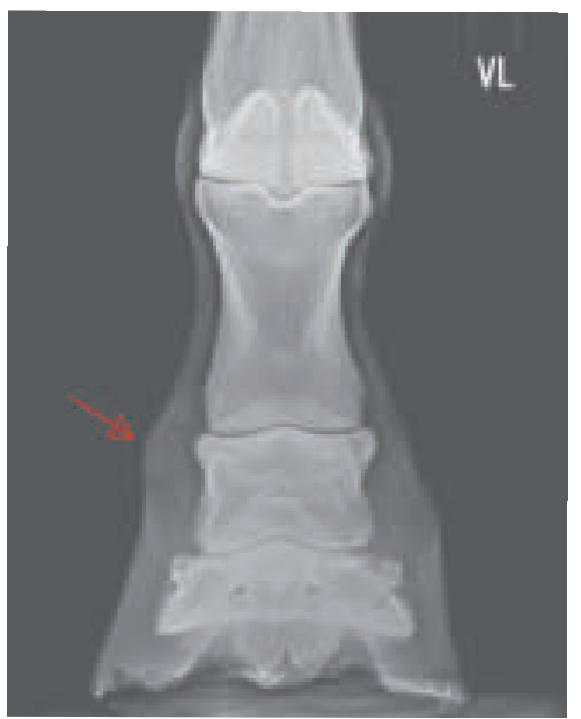

Fig. 1 Dorso-palmar radiograph of the left front foot showing a soft tissue swelling on the medial site at the level of the coronary band (red arrow)

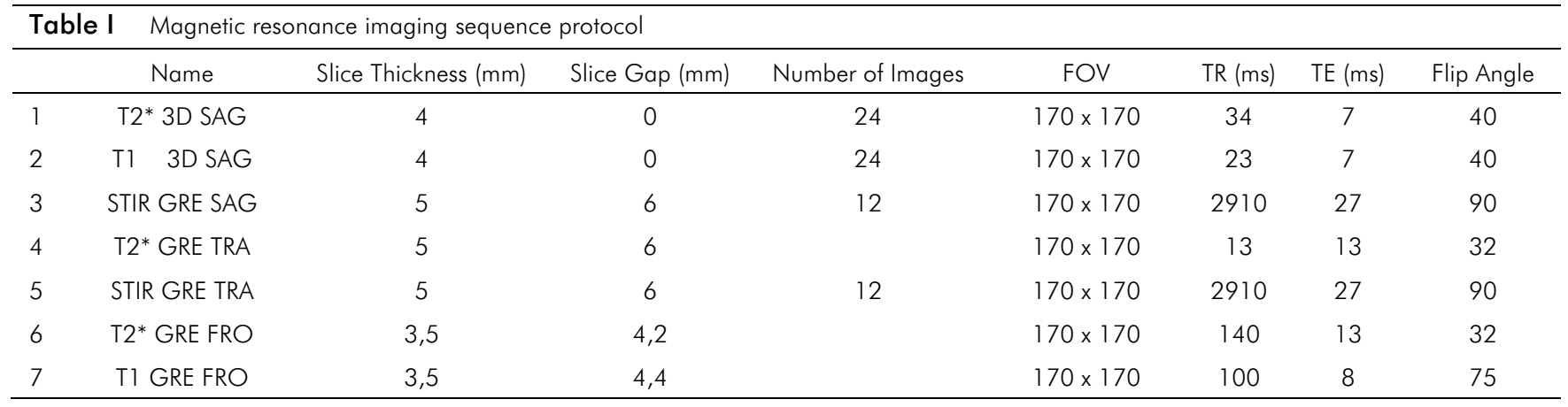


could be visualized in the dorsomedial area of the middle phalanx. In the transverse T2-weighted images, the lateral collateral ligament of the coffin joint appeared almost completely hyperintense (Fig. 3 yellow arrow). The frontal T1-weighted gradient echo sequences showed a superimposition of the articular cartilage lines in the medial area and a focal loss of signal intensity in the articular cartilage of the distal phalanx (see Fig. 4 red arrow). These images also displayed a focal signal decrease in the dorsomedial area (Fig. 4 black arrow).

\section{Therapy and subsequent course}

Since the coffin joint on the MRI images showed an effusion, a puncture of this joint was performed under sterile conditions. $2.4 \mathrm{ml}$ of the synovial fluid were taken. The viscosity was slightly reduced but still stringy. An examination of the synovia with the refractometer showed a protein content of $1.3 \mathrm{~g} / \mathrm{dl}$ and a leucocyte content of $0.8 \mathrm{G} / \mathrm{l}$. The mare was put on strict box rest in a padded box and was supplied with a Robert Jones

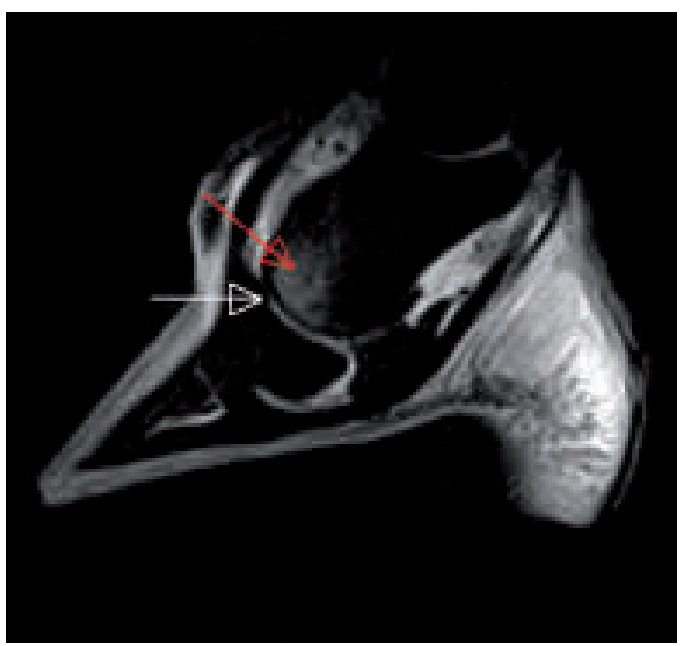

Fig. 2 STIRw sagittal MRI scan showing a focal hyperintense signal dorsally in the subchondral and medullary bone of the pastern bone (red arrow), focal loss of signal in the joint cartilage of the coffin joint (white arrow)

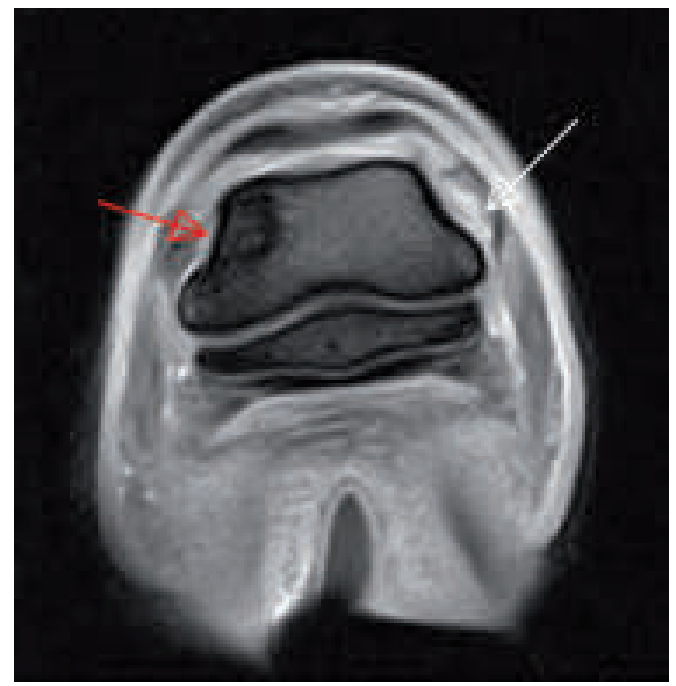

Fig. 3 transversal T2w gradientecho MR scan (GRE) showing a focal hypointens area with a highly hypointense rim in the dorsomedial part of the pastern bone (red arrow), hyperintense signal in the lateral collateral ligament of the coffin joint (white arrow). bandage to the carpal joint. The dressing was changed once a week and left on for a period of 8 weeks. In the first six days of hospitalisation, the mare received intravenous flunixin meglumine (Meflosy ${ }^{\circledR}$, Pfizer) at a dose of $2.2 \mathrm{mg} / \mathrm{kg}$ bw twice daily. The load on the limb improved only moderately at the beginning and worsened again after a few steps.

After discontinuation of the above medication the function remained constant. At rest the mare, at that time, loaded all four limbs equally. Subsequently, seven days after presentation, disodium clodronate at a dose of $3 \mathrm{mg} / \mathrm{kg} \mathrm{bw} / \mathrm{d}$ (Bonefos ${ }^{\circledR}$, Bayer AG) was administered intramuscularly for ten days. Eight weeks after the onset of the lameness, the mare was sound when walking and the initial swelling in the area of the coronary band had disappeared. The horse was then walked at hand for ten minutes a day. Fourteen weeks after the onset of the lameness, the horse was worked again easily in walk and trot under saddle. Five months later, the mare was still sound and in increased equestrian use.

\section{Discussion}

The medullary bone, together with the cortical bone and the subchondral bone are the important components for function and stability. Both tractive and compression forces as well as hormonal influences lead to an adaptation processes of these bone components, which is achieved by a finely modulated activity of osteoclasts and osteoblasts (Kiuru 2005).

Changes in the trabecular bone in the early stage are displayed highly sensitive and specifically only by magnetic resonance imaging. Recently, several reports have been published which describe bone marrow oedema like lesions of the medullary bone of the navicular and the short pastern bone in lame horses (Dyson 2005, Olive et al. 2009, Holowinski et al. 2010). All cases showed a characteristic signal alteration, which could be detected only by magnetic resonance imaging and, unlike similar changes in other bones of the limb, showed no increased uptake in scintigraphy (Murray 2011 ).

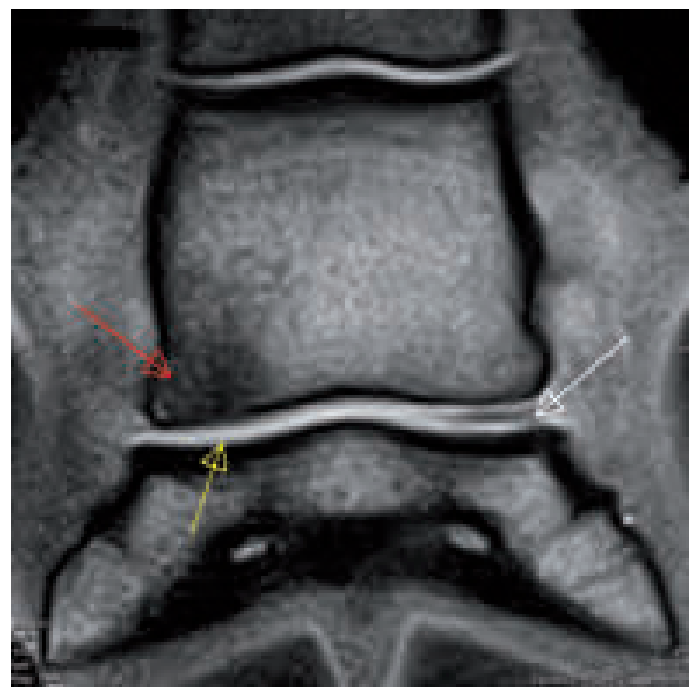

Fig. $4 \quad T 1^{*} w$ gradient echo (GRE) MR scan showing a focal hypointense signal in the pastern bone (red arrow), a focal hypointense signal in joint cartilage (white arrow), it is impossible to evaluate the joint cartilage medial (yellow arrow) 
To the author's knowledge, there are no reports of a correlation between severe lameness and bone oedema like lesions. All reports published on the subject describe lameness that persisted several weeks or even months, and was not, as in this case, acute (Dyson 2005, Olive et al. 2009, Holowinski et al. 2010.).

Bone tissue is subject to constant remodelling and adaptation processes. In the beginning of the adaptation to an altered load these changes are often not immediately visible but, after weeks or months, leaving stable bone tissue adapted to prevailing traction and compression forces. If there is any disturbance of these finely modelled processes, or if the bone tissue is not given sufficient adaptation time, pathological changes of the medullary bone such as microfissures, sclerosis of the subchondral bone, loss of structure of the medullary bone, periosteal proliferations, a demineralization of the cortex and bone oedema like changes occur.

In human medicine, changes in the trabecular portion of the bone are a longer known phenomenon which can be found most frequently in soldiers and athletes, but also in recreational athletes after starting a demanding sport. It was found that the number of injuries of the cancellous bone rise towards the end of very intense training units (Kiuru et al. 2005).

Repeated loading of the bone leads to an activation of osteoclasts, which resorb bone tissue (Chamay and Tschants 1972, Carter et al. 1983, Burr 1985). The maximum osteoclast activity is reached after about three weeks (Jones et al. 1989, Sterling et al. 1992). Thereafter, the channels formed by the osteoclasts are filled with new bone tissue. This process can take up to three months (Frost 1991, Sallis and Jones 1991).

A main factor that leads to diseases of the medullary bone is repeated, mechanical loading, with the magnitude of the load being directly correlated with the degree and the frequency of occurrence (Marti et al. 1988). Also the ratio of loading and rest plays a role (Nordin and Frankel 1989). Human medical studies showed an aetiological correlation between deformities of the limbs and the occurrence of such changes. Decreased bone density as predisposing factor is controversial in human medicine (Benell et al. 1996). A single massive trauma in terms of compression or strain of bone and soft tissue represents another cause of injury to the medullary bone (van Hoencker 2007, Hayes et al. 2000).

In the case presented here, it cannot be stated with certainty which triggering factors should be considered. Conceivable are both a pre-damage of the bone by previous initial training combined with a trauma during grazing, as well as a solitary trauma. The soft tissue swelling of the dorsomedial coronary band can be both caused by a single trauma, in which case often an injury to the skin or a loss of the coat would occur, and can also indicate a continuing trauma to the underlying bone. Lassus et al. (2002) in a human medical study report on a correlation between bone marrow oedema like lesions and swelling of the surrounding soft tissue.

The clinical relevance of the various MRI signal alterations in the spongiosa as well as their correlation with diseases of the surrounding soft tissue or the occurrence of osteoarthritis are not fully understood and discussed controversially in the medi- cal literature. It must also be taken into account that the term bone marrow lesions (BML) or bone marrow oedema like lesion merely describes a characteristic signal change in the MR image of the medullary bone whose underlying cause can be a variety of histopathological conditions (Holowinski et al. 2010). Bone oedema like lesions show increased signal intensity in fat-suppressed and spin echo sequences and decreased signal intensity in T1 - and T2-weighted gradient echo sequences (see Fig. II, III, IV). Histologically these areas of altered signal intensity are inconsistent and only on rare occasions a histological oedema is discovered (Olive et al. 2009).

While some human medical authors rate bone oedema like lesions as a nonspecific finding that is no longer visible by MRI as soon as the osteoclast resorption is completed and new bone is formed, more recent studies assign an important role to the bone oedema. In a human medical study with 1500 patients it could be shown that bone oedemas visible on MR images are closely linked to pathological changes of the subchondral bone (Roemer et al. 2009). Also Zhao and co-workers (2010) found a correlation between the degeneration of the knee joint cartilage and the onset of bone oedema like lesions in the adjacent bone. Due to the strong innervation of the medullary bone, it seems likely that bone oedema like lesions lead to pain and therefore to lameness. But this opinion is assessed inconsistently in the human medical literature. While some authors see a correlation between pain and the occurrence of bone oedema like lesions (Felson et al. 2001, Lo et al. 2009), others could not make this connection (Link et al. 2003, Sowers et al. 2003). Nevertheless, it is definite that a massive activation of osteoclasts leads to considerable bone pain (Mannix et al. 2000).

The mare in the case described here showed significant acute pain symptoms. Magnetic resonance imaging revealed severe bone oedema like lesions in the area of the medullary bone of the distal phalanx as the primary diagnosis. This finding was considered to be the cause of the acute severe lameness. Because of the very high degree of the lameness diagnostic anaesthesia was initially waived, only the conduction anaesthesia carried out at the level of the proximal sesamoid bones before the MRI and the resulting full weight bearing showed that the causing pain was located in the distal toe.

The puncture of the distal interphalangeal joint showed a slightly increased protein content as well as leucocyte content of the synovial fluid. A trauma to the distal interphalangeal joint in terms of an aseptic or septic arthritis therefore seems to be an unlikely cause of pain. If or to which extent the articular cartilage of the middle phalanx was damaged by the underlying bone oedema could not be determined conclusively. One should note, though, that superficial defects and defects such as fibrillations and increased absorption of water into the cartilage cannot be visualized with low-field systems (Schulze et al. 2008). The overlay on the articular cartilage surfaces in the medial part of the joint to be seen on the frontal T1-weighted gradient echo sequences (Fig. I) is likely due to the limb not standing entirely perpendicular to the ground. Whether this correlation exists or if this striking mediolateral imbalance is due to an extensive loss of articular cartilage, has not yet been investigated by any MRI study and might be an interesting starting point for further research. 
The hyperintense signal in the lateral collateral ligament to be seen on the transverse T2-weighted gradient echo sequences is most likely due to a "magic angle" artefact. The "magic angle" effect is based on a variable T2-relaxation, depending on the orientation of the collagen fibres to the main magnetic field. It is most pronounced when the collagen fibres are oriented at an angle of approximately $55^{\circ}$ to the magnetic field and leads to an increase in signal intensity via a prolonged T2 relaxation (Erickson et al. 1993; Gray et al. 1995).

For the interpretation of magnetic resonance images of the bone the comparison of T1-, T2- and STIR-weighted sequences is of utmost importance. Artefacts must also be considered when making the diagnosis - in particular the phase cancellation artefact and, more common in the low field, nonoptimal fat suppression on STIR sequences. A signal loss of the medullary bone in a $T 1$-weighted sequence can be regarded as sclerosis, fibrosis, necrosis, or as a bone oedema like lesion (Werpy et al. 2006, Sherlock et al. 2007). Only the sclerosis of the bone shows a hypointense signal in all sequences, whereas all the other changes described above lead to different signal alterations in T2-weighted gradient and spin echo sequences (d'Anjou et al. 2008).

In T2-weighted gradient and spin echo sequences liquids are shown as a hyperintense signal. Due to phase cancellation artefacts it may be difficult to distinguish a sclerosis of the medullary bone from an accumulation of fluid in T2*-weighted gradient echo sequences (Werpy 2009) when using the Equine Distal Limb Scanner (Hallmarq Ldt.). If using gradient echo sequences with an echo time of 13,39 or 52 ms the signals of fat and liquid, when present in equal amounts, neutralize each other and the tissue is falsely visualized as hypointense (black) (Hood et al. 1999, Werpy 2009). If more fluid than fat tissue is present in the medullary bone, this area is visualized "normal" again, thus intermediate to hyperintense (Werpy 2009, Olive et al. 2009). If there is a violation of the medullary bone, fat and liquid are simultaneously present in the same area, which makes the previous considerations important for the correct interpretation of MRI findings in bone tissue.

STIR sequences are very sensitive and specific in the detection of fluid in the medullary bone (Werpy 2009, Olive et al. 2009, Holowinski et al. 2010). Also, these sequences are very sensitive to motion which makes the detection of sclerosis of the trabecular bone impossible. If the fat signal is not suppressed optimally, fluid and fat tissue are visualized equally hyperintense. Different from the T1 and T2 gradient echo sequences the T2-weighted spin echo sequence used in this case did not show any changes in the medullary bone. Due to the high signal intensity of both fat tissue and fluid a distinction in the magnetic resonance image is not possible (Werpy 2009).

In the present case, the STIR sequence showed a hyperintensity in the dorsomedial region of the medullary bone in the transverse and sagittal projection (see Fig. II). In the T2* gradient echo (GRE) sequences, again in any projection, a focal signal decrease with a significantly hypointense rim area and a central signal increase in the dorsomedial region of the distal short pastern bone could be seen (see Fig. III). In the described localization, a signal decrease of lesser extent was also visible in the T1 GRE sequences (see Fig. IV).
The treatment of bone oedema like lesions in equine medicine has not been studied yet. Factors that make a prognostic assessment of such diseases possible are not yet known (Olive et al. 2009, Werpy 2009). Olive et al. (2009) assume that for horses not responding to treatment within three to four months, the prognosis in terms of soundness is significantly worse. In human medicine, a cornerstone of therapy seems to be the immobilization of the affected limb. The duration and degree of immobilization depends on the extent of the changes. This is followed by a period in which the patient does not fully load the limb, which is achieved by cycling or swimming. The treatment at the beginning of the disease, especially when accompanied by poor limb function, can be supported with NSAIDs, but the potential osteoblast inhibitory effect of these agents must be taken into account (Lassus et al. 2002). To our knowledge there are no reports on the use of bisphosphonates for this indication in the medical literature. Nevertheless, a bone pain relieving effect is described (Mannix et al. 2000). To which extent the osteoclast inhibitory effect of bisphosphonates contributed to the success of therapy in the present case cannot be conclusively proven. However, since bone oedema like lesions may be triggered by increased osteoclastic activity, the use of bisphosphonates seems to make sense. Janssen et al. (2012) treated lame horses with a signal increase in the navicular bone with calcium dobesilate. In 11 out of 12 patients an improvement of the lameness could be observed. In the MRI follow-up a reduction of the hyperintense signal in the navicular bone showed in the STIR sequences. A correlation between the treatment with calcium dobesilate and an improvement of the lameness as well as a reduction of the MR signal in the navicular bone could not be shown by the authors. Whether a surgical intervention in terms of decompression of the intraosseous pressure by drilling the bone and opening the cortex is a therapeutic option may not yet be stated. So far this approach is only described in two cases of bone oedema like lesions in the navicular bone. After the surgery, the patients were clinically improved (Murray 2011 ). In human medicine, this surgical procedure is applied with success mainly in bone oedema like lesions in the area of the femoral head (Hofmann et al. 1993).

In the patient described here a significant improvement of the load or function of the limb could be achieved by applying a Robert Jones bandage and the resulting immobilization. Moreover, to further unload the limb with a suspension device such as the Horse Swinglifter (Michael Puhl GmbH, Germany) would be useful. To which extent and whether bone oedema like lesions play a role in degenerative joint and bone disorders is not yet known. Magnetic resonance imaging studies of horses before the start of their sporting careers and further follow-up examinations during their sporting use are desirable to be able to show any possibly existing correlations between bone oedema like lesion and degenerative joint and bone diseases at multiple sites. This connection has already been established in a large number of patients in human medical studies (Zhao et al. 2010).

\section{References}

Benell K. L., Malcolm S. A., Thomas S. A., Wark J. D., Bruckner P. D. (1996) The incidence and distribution of stress fractures in competitive track and field athletes. A twelve-month prospective study. Am. J. Sports Med. 24, 211-217 
Burr D. B., Martin R. B., Schaeffler M. B. (1985) Bone remodelling in response to in vivo fatigue microdamage. J. Biomech. 18, 189-200

Carter D. R., Caler W. E. (1983) Cycle- dependent and time- dependent bone fracture with repeated loading. J. Biomech. Eng. 105, 166-170

Chamay A., Tschants P. (1972) Mechanical influence in bone remodeling: experimental research on Wolf's law. J. Biomech. 2, 173-180

Chapurlat R. D., Delmas P. D., Liens D., Meunier P. J. (1997) Longterm effects of intravenous pamidronate in fibrous dysplasia of bone. J. Bone Miner. Res. 12, 1746-1752

d'Anjou, M.-A, Trancy E., Moreau M., Abram F., Raynauld J.- P., Martel-Pelletier J., Pelletier J.-P. (2008) Temporal assessment of bone marrow lesions on magnetic resonance imaging in a canine model of knee osteoarthritis: impact of sequence selection. In: Osteoarthr. Cartil., Jg. 16, S. 1307-1311

Denoix J. -M, Thibaud D., Riccio B. (2003) Tiludronate as a new theapeutic agent in the treatment of navicular disease: a double- blind placebo- controlled clinical trial. In: Equine Vet. J. 35, 407-413

Dyson S. J., Murray R., Schramme M. C. (2005) Lameness associatd with foot pain: results of magnetic resonance imaging in 199 horses (January 2001 - December 2003) and response to treatment. Equine Vet. J. 37, 113-121

Dyson S. J., Ross M. W. (2003) Diagnosis and Management of Lameness in the Horse. Saunders, St. Louis, Missouri, 1. Auflage

Janssen I., Mair T., Reardon R., Werver M., Fricker C., Kremer F., Lischer C. (2012) Effects of Calcium dobesilate on horses with an increased signal intensity in the navivular bone in fat suppressed images on MRI: Pilot study. Pferdeheilkunde 27, 601-608

Felson D. T., Chaisson C. E., Hill C. L., Totterman S. M., Gale M. E., Skinner K. M., Kazis L., Gale D. R. (2001) The association of bone marrow lesions with pain in the knee osteoarthritis. Ann. Intern. Med. 134, 541-549

Frost H. M. (1991) Some ABC's of skeletal patho- physiology vs. microdamage physiology. Calcif. Tissue Int. 49, 229-231

Hayes C. W., Brigido M. K., Jamadar D. A., Propeck T. (2000) Mechanism-based pattern approach to classification of complex injuries of the knee decitep at MR imaging. Radiographics 20, 121-134

Hofmann S., Engel A., Neuhold A., Leder K., Kramer J., Plenk H. Jr. (1993) Bonemarrow oedema syndrome and transient osteoporosis of the hip. An MRI controlled study of treatment by core decompression. J. Bone Joint Surg. Br. 75, 210-216

Holowinski M., Carter J., Travis S., Louise M. (2010) Resolution of lesions on STIR images is associated with improved lameness status in horses. Vet. Radiol. Ultrasound 51, 479-484

Jones B. H., Harris J., Vinh T. N. (1989) Exercise- induced stress fractures and reactions of bone. Epidemiology, etiology and classification. Exerc. Sports Sci. Rev. 17, 379-422

Kiuru M. J., Niva M., Reponen A., Pihlajamaki H. K. (2005) Bone stress injuries in asymptomatic elite recruits: a clinical and magnetic resonance imaging study. Am. J. Sports Med. 33, 272-276

Kiuru M. J., Pihlajamaki H. K., Ahovuo J. A. (2004) Bone stress injuries. Acta Radiol. 45, 317-326

Lassus J., Tulikoura I., Konttinen Y. T., Salo J., Santavirta S. (2002) Bone stress injuries of the lower extremity. Acta Orthop. Scand. 73, 359-368

Link T. M., Steinbach L. S., Ghosh S., Ries M., Lu Y., Lane N., Majumdar S. (2003) Osteoarthritis: MR imaging findings in diffeent stages of the disease and correlation with clinical findings. Radiology 226, 373-381

Lo G., McAlindon T., Niu J., Zhang Y., Beals C., Dabrowski C., Hellio Le Graverand M. P., Hunter D. J. (2009) Bone marrow lesions and joint effusion are strongly and independently associated with weight- bearing pain in knee osteoarthritis: data from the osteoarthritis initiative. Osteoarthr. Cartil. 17, 1562-1569

Mannix K., Hiemeland S., Anderson H., Bennett M., Lloyd-Williams M., Willcock A. (2000) Using bisphosphonates to control the pain of bone metastases: evidence- based guidelines for palliative care. Palliat. Med. 15, 141-147

Marti B., Vader J. P., Minder C. E. (1988) On the epidemiology of running injuries. The 1984 Berne Grand Prix study. Am. J. Sports Med. 16, 285-294
McGibbon C. A.; Bencardino J.; Palmer W. E. (2003) Subchondral bone and cartilage thickness from MRI: effects of chemical-shift artifacts. Magn. Reson. Mat. Phys. Biol. Med. 16, 1-6

Murray C. (2011) Equine MRI, Wiley- Blackwell, West- Sussex, 1. Auflage.

Nordin M., Franke/ V. H. (1989) Biomechanics of the hip. In: Basic biomechanics of the musculoskeletal system. 2nd edition, 135-151

Olive J., Mair T. S., Charles B. (2009) Use of standing low- field magnetic resonance imaging to diagnose middle phalanx bone marrow lesions. Equine Vet Educ 21, 116-123

Sallis R. E., Jones K. (1991) Stress fractures in the athlete: How to spot this undiagnosed injury. Post. Grad. Med. 89, 185-192

Sherlock C. E., Kinns J., Mair T. S. (2007) Evaluation of foot pain in the standing horse by resonance imaging. Vet. Rec. 161, 739-764

Sowers M. F., Hayes C., Jamadar D. A., Capul D., Lachance L., Jannausch M., Welch G. (2003) Magbetic resonance- detected subchondral bone marrow and cartilage defect characteristics associated with pain an X-ray-defined knee osteoathritis. Osteoarthr. Cartil. 11, 387-393

Sterling J. C., Edelstein D. W., Calvo R. D., Webb R. (1 192) Stress fractures in the athlete: diagnosis and management. Sports Med 14, 336-346

Vanhoeacker F. M., Snoeckx A. (2007) Bone marrow edema in sports: general concepts. Eur. J. Radiol. 62, 6-15

Werpy N. (2009) Diagnosis of middle phalanx bone marrow lesions in horses using magnetic resonance imaging and identification of phase effect cancellation for proper imaging interpretation. Equine Vet. Educ. 21, 125-130

Zhao J., Li X., Bolbos R., Link T. M., Majumdar S. (2010) Longitudinal assessment of bone marrow edema- like lesions and cartilage degeneration in osteoarthritis using 3 T MR T1 rho quantification. Skeletal Radiol. 39, 523-531

\section{Knochenödem-ähnliche Veränderungen des medullären Knochens} des Kronbeins als Ursache einer hochgradigen Lahmheit bei einer 4-jährigen Trakehner-Stute

Zusammenfassung: Im Zusammenhang mit dem Auftreten von Lahmheiten beim Pferd werden seit einiger Zeit Erkrankungen des Knochens diskutiert, die sich durch ein erhöhtes Signal in fettunterdrückten MR-Sequenzen (STIR) und einer Signalerniedrigung in T1- und T2-gewichteten Gradientenechosequenzen (GRE) in einem Niedrigfeldscanner darstellen. Diese, in der englischen Literatur häufig als "bone marrow edema like lesions" benannten Veränderungen, wurden beim Pferd im Strahlbein, im Kronbein, in den distalen Enden der Metacarpal und -tarsal Knochen und in den Knochen des Karpalgelenks gefunden. Histologisch werden "bone marrow edema like lesions" als Nekrosen, Fibrosen und nur selten als Ödeme angesprochen. In der humanmedizinischen Literatur sind "bone marrow oedema like lesions" schon länger beschrieben. Sie konnten sowohl bei klinisch auffälligen und unauffälligen Patienten gefunden werden. Auch wird in der humanmedizinischen Literatur ein Zusammenhang zwischen dem Auftreten von 
„bone marrow edema like lesions" und Osteosrthritiden diskutiert. Eine 4-iährige Trakehnerstute zeigte nach einer 6-wöchigen Anreitphase eine höchstgradige Lahmheit. Mit Hilfe eines Niedrigfeldkernspintomographens $(0,27 \mathrm{~T})$ konnte ein "bone marrow edema like lesion" im Bereich des Kronbeins gefunden werden. Dieses zeigte sich durch eine Signalerhöhung in den fettunterdrückten (STIR) und Signalerniedrigung in den T1 - und T2-gewichteten Gradientenechosequenzen (GRE). Auf den durchgeführten Spinechosequenzen konnte keine Signalalteration innerhalb des Kronbeins gezeigt werden. Erst durch einen über einen Zeitraum von sechs Wochen angelegten RobertJones Verband konnte eine Belastung der Gliedmaße und eine daverhafte Nutzung des Pferdes erreicht werden.

Schlüsselwörter: MRT/ Pferd/ "bone oedema like lesions"/ Knochenödem/ Lahmheit / Orthopädie / bildgebende Diagnostik

\section{Einleitung}

Bei Auftreten von plötzlichen, hochgradigen Lahmheiten müssen folgende Erkrankungen differentialdiagnostisch in Betracht gezogen werden: Fraktur bzw. Fissur eines GliedmaBenknochens, Pododermatitis circumscripta septica und Gelenk- bzw. Sehnenluxation (Ross and Dyson 2005). Ferner muss auch eine einseitig auftretende Hufrehe in Betracht gezogen werden.

Veränderungen im Sinne eines Knochenödems können nur mit Hilfe der Kernspintomographie sicher diagnostiziert werden (Olive et al. 2010). Sie gehören zu einem Krankheitskomplex, der in der englischsprachigen Literatur als "bone marrow lesions" bezeichnet wird. In der Pferdemedizin existieren nur wenige Fallberichte, die knochenödem-ähnliche Veränderungen des Kronbeins oder Strahlbeins als Ursache für eine Lahmheit beschreiben (Dyson et al. 2005, Olive et al. 2010, Janssen et al. 2011 ). Sowohl in der Humanmedizin als auch in der Pferdemedizin ist die klinische Signifikanz der knochenödem-ähnlichen Veränderungen noch nicht abschließend geklärt. Sie treten sowohl bei klinisch unauffälligen als auch bei klinisch auffälligen Individuen auf (Kiuru 2005, Olive et al. 2010, Werpy 2010) und in Bezug auf die ätiologischen Zusammenhänge sind noch Fragen offen. In der Literatur werden drei verschiedene Ätiologien diskutiert. Zum einen wird von einer initialen Traumatisierung des Knochen- und umgebenden Weichteilgewebes im Sinne einer Stauchung und Zerrung ausgegangen. Andere Autoren sehen eine Belastung des Knochens über seine Anpassungsfähigkeit hinaus als ursächlich an. Zuletzł wird eine Störung des Knochenstoffwechsels hinsichtlich der feinen hormonellen Modulation als eine mögliche Ätiologie angesehen (Kiuru 2005).

Aufgrund der noch ungeklärten Ätiologie und der geringen Erfahrung dieser Erkrankung in der Orthopädie des Pferdes und ihrer Korrelation zur Humanmedizin, ist die Therapie solcher knochenödem-ähnlichen Veränderungen schwierig. Jedoch findet sich übereinstimmend bei allen Therapieansätzen der Hinweis auf eine deutliche Reduktion der Belastung ohne vollständige Ruhigstellung. Hinsichtlich der medikamentellen Therapie bei Pferden wird der Einsatz von Bisphosphonaten beschrieben (Bathe 2011, Janssen et al. 2011). In der veterinärmedizinischen Literatur wird die Prognose quo ad restitutio et integrum als schlecht angegeben, wobei hier beachtet werden muss, dass sich die Einschätzung nur auf die Ergebnisse weniger Fallberichte stützt.
Bei einer jungen Trakehnerstute, die nach sechs wöchiger Anreitphase auf der Weide gehalten wurde, war akut eine hochgradige Stützbeinlahmheit der linken Vordergliedmaße aufgetreten. Mit Hilfe der üblichen bildgebenden Verfahren (Röntgen, Ultraschall) wurde kein Hinweis auf die Ursache der Schmerzhaftigkeit festgestellt. Bei der kernspintomographischen Untersuchung der distalen Zehe der linken Vordergliedmaße waren Befunde im Sinne eines Knochenödems im Kronbein festzustellen. Einen Hinweis auf die Lahmheitsursache und eine Diagnose wurde im vorliegenden Fall allein mit Hilfe der magnetresonanztomographischen Untersuchung gestellt.

\section{Fallbericht}

Anamnese

Die vieriährige in Dressur gearbeitete Trakehner-Stute fiel nach sechswöchiger Anreitphase und anschließendem zweitägigen Weideaufenthalt mit einer höchstgradigen Stützbeinlahmheit der linken Vordergliedmaße auf. Bei der klinischen Untersuchung durch den überweisenden Haustierarzt fiel eine geringradig schmerzhafte und nicht vermehrt warme Schwellung dorsomedial am Kronrand auf. Des Weiteren wurde eine geringgradige Pulsation der Aa. digitales lateralis und medialis festgestellt werden. Die Hufzangenuntersuchung verlief negativ. Da ein Frakturverdacht bestand, wurden durch den überweisenden Haustierarzł zunächst Röntgenaufnahmen mit lateromedialem und dorsopalmarem Strahlengang sowie eine Aufnahme nach Oxspring der linken distalen Vordergliedmaße angefertigt. Jedoch konnten keine radiologischen Befunde erhoben werden, die Auftreten und Grad der Lahmheit erklärt hätten.

Das Pferd wurde aufgestallt und mit einem Röhrenpolsterverband und einem Hufangussverband versorgt. Es erhielt zweimal täglich nicht-steriodale Antiphlogistika oral durch den Besitzer. Die hochgradige Lahmheit verbessert sich unter dieser Therapie in den folgenden Tagen kaum. So dass die Stute vier Tage nach Auftreten der Lahmheit in die Klinik der Verfasser eingeliefert wurde.

Ergebnisse der Allgemeinuntersuchung und der klinischen orthopädischen Untersuchung

Bei Aufnahme in die Klinik zeigte die Stute ein deutlich gestörtes Allgemeinbefinden sowie eine höchstgradige Lahmheit der linken Vordergliedmaße. Ein Aufheben der kontralateralen Gliedmaße war nicht möglich. Eine ggr. Pulsation war an den Aa. digitalis laterales et medialis auf Höhe der Gleichbeine palpierbar. Im Bereich des Kronsaum befand sich eine circa 1,5 cm hohe Schwellung, die sich von der dorsalen Mittellinie bis medial in den Trachtenbereich zog. Bei der Palpation war diese Schwellung ggr. schmerzhaft und vermehrt warm, von derber Konsistenz und nicht verschieblich. Die Untersuchung mit der Hufzange verlief negativ.

\section{Ergebnisse der röntgenologischen Untersuchung}

Es wurden Aufnahmen im lateromedialem, dorsopalmarem, dorsolateralem-palmaromedialem, dorsomedialem-palmarolateralem Strahlengang und eine Aufnahme nach Oxspring angefertigt. Hier konnte die vorher während der klinischen Untersuchung auffällige Weichteilschwellung im Bereich des 
Kronrandes nachvollzogen werden (s. Abbildung I). Jedoch wurden wiederum keine röntgenologischen Befunde erhoben, die einen derartigen Grad der Lahmheit erklärten. Da weder durch die klinische noch durch die radiologische Untersuchung eine Ursache der Lahmheit festgestellt wurde, erfolgte eine kernspintomographische Untersuchung am sedierten, stehenden Pferd.

In Vorbereitung auf die kernspintomographische Untersuchung wurde die Stute mit Romifidine 0,08 mg/Kg i.v. (Sedi$\operatorname{vet}^{\circledR}$, Boehringer Ingelheim) sediert und eine Leitungsanästhesie der $\mathrm{Nn}$. Palmares digitales lateralis et medialis mit $6 \mathrm{ml}$ $2 \%$ iger Mepivacainhydrocloridlösung (Scandicain ${ }^{\circledR}$ AstraZeneca) auf Höhe der proximalen Sesambeine (MPA) durchgeführt. Die Stute belastete daraufhin die Gliedmaße im Schritt gut. Die Sequenzen der kernspintomographischen Untersuchung( Equine Distal Limb Scanner, Hallmarq Veterinary Imaging Ltd) sind aus Tabelle 1 ersichtlich.

\section{Ergebnisse der kernspintomographischen Untersuchung}

Die Auswertung der kernspintomographischen Bilder erfolgt mit der Dicombetrachtersoftware der Firma Oehm und Rehbein (dicomPACSvet, Oehm und Rehbein, Rostock). Die Bilder wurden auf einem Plasmabildschirm ausgewertet (NEC MultiSync MD301C4, NEC München).

Folgende Befunde konnten erhoben werden. Auf der sagitalen STIR Aufnahme zeigte sich ein fokaler, hyperintenser Bereich, der sich vom subchondralen Knochen bis in den medullären Knochen erstreckt. Auf einem dieser STIRgewichteten Schnittbilder konnte eine Unterbrechung der Gelenkknorpellinie gesehen werden (siehe Abb. 2). Auch zeigte sich auf diesen Aufnahmen ein mittelgradig vermehrt gefüllter Recessus dorsalis und palmaris des Hufgelenks. Auf den T2-gewichteten Gradientenechosequenzen sowohl in dorsaler als auch in transversaler Ausrichtung konnte im dorsomedialen Bereich des Kronbeins ein fokaler, hypointenser Bereich mit einem sehr hypointensen Randbereich dargestellt werden (siehe Abb. III u. IV). Auf den transversal ausgerichteten T2-gewichteten Schnittbildern erschien das laterale Kollateralband des Hufgelenks fast komplett hyperintens (siehe Abb. 3 gelber Pfeil).

Die frontal augerichteten T1-gewichteten Gradientenechosequenzen zeigten eine Überlagerung der Gelenkknorpellinien im medialen Bereich und einen fokalen Verlust der Signalintensität im Gelenkknorpel des Hufbeins (Abb. 4 roter Pfeil). Auch auf diesen Schnittbildern zeigte sich eine fokale Signalerniedrigung im dorsomedialen Bereich (Abb. 4 schwarzer Pfeil).

\section{Therapie und weiterer Verlauf}

Da sich das Hufgelenk in den kernspintomographischen Bildern vermehrt gefüllt darstellte, wurde unter sterilen Kautelen eine Punktion dieses Gelenks durchgeführt. Es wurden 2,4 ml entnommen. Die Viskosität der Synovia war ggr. vermindert aber noch fadenziehend. Die Betrachtung der Synovia im Refraktometer ergab einen Proteingehalt von 1,3 g/dl und einen Leukozytengehalt von 0,8 G/L. Die Stute erhielt strikte Boxenruhe in einer gepolsterten Box und wurde mit einem Robert-Jones-Verband bis zum Karpalgelenk versorgt. Der Verband wurde wöchentlich gewechselt und verblieb über einen Zeitraum von 8 Wochen. In den ersten sechs Tagen des stationären Aufenthaltes erhielt die Stute zweimal täglich

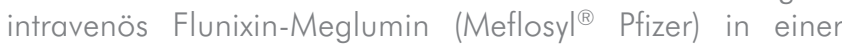
Dosierung von $2,2 \mathrm{mg} / \mathrm{kg} \mathrm{KGW}$.

Die Belastung der Gliedmaße verbesserte sich zu Beginn nur mäßig und verschlechterte sich nach wenigen Schritten Belastung. Nach Absetzten der oben genannten Medikation war die Funktion gleichbleibend Im Stand der Ruhe belastete die Stute zu diesem Zeitpunkt alle vier Gliedmaßen gleichmäßig. Daraufhin wurde sieben Tage nach Vorstellung wurde Dinatriumclodronat in einer Dosierung von $3 \mathrm{mg} / \mathrm{kg} \mathrm{KGW} / \mathrm{Tag}$ (Bonefos ${ }^{\circledR}$ Bayer AG) über zehn Tage intramuskulär verabreicht. Acht Wochen nach dem ersten Auftreten der Lahmheit war die Stute im Schritt lahmfrei und auch die zunächst festgestellte Schwellung im Bereich des Kronsaums war nicht mehr vorhanden. Das Pferd wurde daraufhin täglich zehn Minuten an der Hand geführt. Vierzehn Wochen nach Auftreten der Lahmheit wurde das Pferd wieder leicht im Schritt und Trab unter dem Sattel gearbeitet. Fünf Monate später war die Stute immer noch lahmfrei und befand sich in gesteigerter reiterlicher Nutzung.

\section{Diskussion}

Der medulläre Knochen stellt zusammen mit der Korticalis und dem subchondralen Knochen die funktionell wichtigen Komponenten für die Funktion und Stabilität dar. Durch Zug- und Druckkräfte aber auch durch hormonelle Beeinflussung kommt es zu Anpassungsvorgängen dieser Knochenkomponenten, die durch eine fein modulierte Osteoklasten- und Osteoblastenaktivietät erreicht werden (Kiuru 2005): Veränderungen des trabekulären Knochens sind in der Frühphase hoch sensitiv und spezifisch nur durch die Kernspintomographie darstellbar. In jüngerer Zeit wurden einige Berichte publiziert, die Signalalterationen im Sinne von "bone marrow edema like lesions" des medullären Knochens von Strahl- und Kronbein beschreiben, die bei lahmen Pferden gesehen wurden. (Dyson 2005, Olive et al. 2009, Holowinski et al. 2010). Allen Fällen war eine charakteristische Signalalteration gemeinsam, die nur mit Hilfe der Kernspintomographie nachgewiesen werden konnte und anders als ähnliche Erkrankungen an anderen Knochen der Gliedmaße keine vermehrte Anreicherung in der Szintigraphie zeigten (Murray 2011).

Nach Wissen der Autoren existieren aber keine Berichte über einen Zusammenhang zwischen einer hochgradigen Lahmheit und Veränderungen im Sinne von knochenödem-ähnlichen Veränderungen. Alle Berichte, die zu diesem Thema veröffentlicht sind, beschreiben Lahmheiten, die mehrere Wochen oder sogar Monate bestanden und sich nicht wie im vorliegenden Fall in der akuten Phase befanden (Dyson 2005, Olive et al. 2009, Holowinski et al. 2010).

Knochengewebe unterliegt im Körper ständigen Umbau- und Anpassungsprozessen, die häufig zu Beginn nach einer veränderten Belastung nicht sofort sichtbare Anpassung benötigt Wochen bis Monate und hinterlässt stabileres, an die vorherrschenden Zug- und Druckkräfte adaptiertes Knochengewebe. Kommt es zu Störungen dieser feinmodellierten Abläufe, oder wird dem Knochengewebe nicht genügend Anpassungszeit gegeben, treten pathologische Veränderungen des medullären Knochens wie z.B. Mikrofissuren, Sklerosierung des sub- 
chondralen Knochens, Strukturverlust des medullären Knochens, periostale Zubildungen, eine Demineralisierung der Cortex und knochenödem-ähnliche Veränderungen auf.

In der Humanmedizin sind Veränderungen am trabekulären Anteil des Knochens ein bereits länger bekanntes Phänomen, das am häufigsten bei Soldaten und Leistungsportlern, aber auch bei Freizeitsportlern nach Einstig in eine fordernde Sportart nachgewiesen werden kann. Es zeigte sich, dass die Anzahl an Verletzungen im Bereich der Spongiosa zum Ende von sehr intensiven Trainigseinheiten ansteigen (Kiuru et al. 2005). Wiederholte Belastung des Knochens führt zu einer Aktivierung der Osteoklasten, die Knochengewebe resorbieren. (Chamay und Tschants 1972, Carter et al. 1983, Burr 1985). Die maximale Osteoklastenaktivität wird nach circa drei Wochen erreicht. (Jones et al. 1989, Sterling et al. 1992). Danach werden die Kanäle, die durch die Osteoklasten gebildet wurden mit neuem Knochengewebe aufgefüllt. Dieser Prozess kann bis zu drei Monate davern (Frost 1991, Sallis und Jones 1991).

Ein Hauptfaktor, der zu einer Erkrankungen des medullären Knochens führt, ist eine wiederholte mechanische Belastung des Knochens, wobei das Ausmaß der Belastung direkt mit dem Grad und der Häufigkeit des Auftretens korreliert (Marti et al. 1988). Auch das Verhältnis zwischen Belastung und Ruhepausen spielt dabei eine Rolle (Nordin und Frankel 1989). Humanmedizinische Studien zeigten einen ätiologischen Zusammenhang zwischen Fehlstellungen der Gliedmaßen und dem Auftreten solcher Veränderungen. Eine verminderte Knochendichte als prädisponierender Faktor wird in der Humanmedizin kontrovers diskutiert (Benell et al. 1996). Eine einmalige massive Traumatisierung im Sinne einer Stauchung oder Zerrung von Knochen- und Weichteilgewebe stellt eine weitere Ursache für Verletzungen des medullären Knochens dar (Vanhoenacker 2007, Hayes et al. 2000).

Im vorliegenden Fall kann nicht mit Sicherheit gesagt werden, welche auslösenden Faktoren in Betracht gezogen werden können. Denkbar sind sowohl eine Vorschädigung des Knochens durch die vorangegangene Anreitphase im Zusammenhang mit einer Traumatisierung während des Weidegangs als auch eine einmalige Traumatisierung. Die Weichteilschwellung im Bereich des dorsomedialen Kronsaums kann sowohl durch eine einmalige Traumatisierung verursacht werden, wobei hier häufig eine Verletzung der Haut bzw. ein Verlust des Haarkleides zu erwarten ist, als auch auf eine schon länger bestehende Traumatisierung des darunter liegenden Knochens hindeuten. Lassus et al. (2002) berichten in einer humanmedizinischen Studie, dass ein Zusammenhang zwischen dem bestehen von "bone marrow edema like lesions" und der Schwellung des umliegenden Weichteilgewebes besteht.

Neben der klinischen Relevanz der verschiedenen kernspintomographisch sichtbaren Signalalterationen im Bereich der Spongiosa, ist auch ihr Zusammenhang mit Erkrankungen des umgebenen Weichteilgewebes oder dem Auftreten von Osteoathritiden nicht vollständig geklärt und wird in der humanmedizinischen Literatur kontrovers diskutiert. Dabei muss auch bedacht werden, dass der Begriff bone marrow lesions (BML), oder bone marrow edema like lesion lediglich eine Beschreibung einer charakteristischen Signalverände- rung des medullären Knochens im kernspintomographischen Bild beschreibt deren Grundlage eine Vielzahl von histopathologischen Zustände sein können (Holowinski et al. 2010). Knochenödem-ähnliche Veränderungen zeigen in fettunterdrückten Sequenzen und Spinechosequenzen eine erhöhte Signalintensität und in T1- und T2-gewichteten Gradientenechsosequenzen eine erniedrigte Signalintensität (Abb. 2, 3, 4). Histologisch stellen sich diese Bereiche veränderter Signalintensität nicht einheitlich dar und nur selten liegt ein Ödem im histologischen Sinne vor (Olive et al. 2009).

Während einige Autoren aus der Humanmedizin knochenödem-ähnliche Veränderungen als unspezifischen Befund werten, die kernspintomographisch nicht mehr sichtbar sind sobald die durch Osteoklasten bedingte Resorption beendet ist und sich never Knochen bildet, sprechen nevere Studien dem Knochenödem eine wichtige Rolle zu. So konnte in einer humanmedizinischen Studie mit 1500 Patienten gezeigt werden, dass kernspintomographisch sichtbare Knochenödeme eng mit pathologischen Veränderungen des subchondralen Knochens verknüpft sind (Römer et al. 2009). Auch Zhao et al. (2010) stellten einen Zusammenhang zwischen der Degeneration des Kniegelenksknorpel und dem Auftreten von knochenödem-ähnlichen Veränderungen im angrenzenden Knochen aufzeigen. Aufgrund der starken Innervation des medullären Knochens liegt die Vermutung nahe, dass knochenödem- ähnliche Veränderungen zu Schmerzen und damit zu Lahmheiten führen. Diese Meinung wird aber in der humanmedizinischen Literatur unterschiedlich bewertet. Während einige Autoren einen Zusammenhang zwischen Schmerz und dem Auftreten von knochenödem-ähnlichen Veränderungen sehen (Felson et al. 2001, Lo et al. 2009), konnten wiederum andere diesen Zusammenhang nicht herstellen (Link et al. 2003, Sowers et al. 2003). Fest steht aber, dass eine massive Aktivierung von Osteoklasten zu erheblichem Knochenschmerz führt (Mannix et al. 2000).

Die Stute in dem hier beschriebenen Fall zeigte akut eine erhebliche Schmerzsymptomatik. Kernspintomographisch fiel als primärer Befund eine hochgradige Veränderung im Bereich des medullären Knochens des distalen Kronbeins im Sinne einer knochenödem-ähnlichen Veränderung auf. Dieser Befund wurde als ursächlich für die akute hochgradige Lahmheit angesehen. Aufgrund der höchstgradigen Lahmheit wurde zunächst auf diagnostische Anästhesien verzichtet, lediglich die vor der kernspintomographischen Untersuchung durchgeführte Leitungsanästhesie im Bereich der Gleichbeinbasis und die daraus resultierende volle Belastung der Gliedmaße zeigte, dass sich der lahmheitsverursachende Schmerz im Bereich der distalen Zehe befand.

Die Punktion des Hufgelenks ergab einen geringgradig erhöhten Proteingehalt und Leukozytengehalt der Synovia. Eine Traumatisierung des Hufgelenks im Sinne einer aseptischen bzw. septischen Arthritis erscheint also wenig wahrscheinlich in Bezug auf die Schmerzursache. Inwieweit der Gelenkknorpel des Kronbeins durch das unterliegende Knochenödem eine Schädigung erfahren hat konnte abschließend nicht geklärt werden. Hier bleibt lediglich anzumerken, dass oberflächliche Defekte und Defekte, wie Fibrillationen und eine vermehrte Wasseraufnahme in den Knorpel, nicht mit Niedrigfeldsystemen dargestellt werden können (Schulze et al. 2008). Die auf den frontal ausgerichteten T1-gewichte- 
ten Gradientenechosequenzen (Abb. I) zu sehende Überlagerung der Gelenkknorpelflächen im medialen Gelenkbereich ist wahrscheinlich einer nicht ganz lotrecht zum Boden stehenden Gliedmaße geschuldet. Ob dieser Zusammenhang besteht oder diese auffallende medio- laterale Imbalance auf einen großflächigen Verlust des Gelenkknorpels zurück zu führen ist, wurde noch von keiner kernspintomographischen Studie untersucht und stellt noch einen interessanten Ansatzpunkt für weitere Forschung dar.

Das hyperintense Signal im lateralen Kollateralband, das auf den transversalen T2-gewichteten Gradientenechosequenzen zu sehen ist, wird mit hoher Wahrscheinlichkeit durch einen Magic-Angel-Artefakt erzeugt. Der Magic-Angle-Effekt beruht auf einer variablen T2-Relaxation in Abhängigkeit von der Orientierung der Kollagenfasern zum Hauptmagnetfeld. Er ist am stärksten ausgeprägt, wenn sich die Kollagenfasern in einem Winkel von circa 55 Grad zum Magnetfeld befinden und führt durch eine verlängerte T2-Relaxation zu einem Anstieg der Signalintensität (Erickson et al 1993, Gray et al. 1995).

Für die Interpretation von kernspintomograhischen Aufnahmen des Knochens sind der Vergleich von T1-, T2- und STIRgewichteten Sequenzen von äußerster Wichtigkeit. Daneben muss das Auftreten von Artefakten, im Besonderen der "phase-cancellation-Artefakt" und die im Niedrigfeld häufiger auftretende nicht optimale Fettunterdrückung in der STIR Sequenz bei der Befundung in Betracht gezogen werden.

Ein Signalverlust des medullären Knochens in einer T1gewichteten Sequenz kann als Sklerose, Fibrose, Nekrose oder als Knochenödem- ähnliche Veränderung gewertet werden (Werpy et al. 2006, Sherlock et al. 2007). Lediglich die Sklerosierung des Knochens zeigt in allen Sequenzen ein hypointenses Signal, wohingegen alle anderen oben beschriebenen Veränderungen in T2-gewichteten Gradienten- und Spinechosequenzen unterschiedliche Signalalterationen aufweisen ( $d^{\prime}$ Anjou et al. 2008).

In T2-gewichteten Gradienten- und Spinechosequenzen wird Flüssigkeit als hyperintenses Signal dargestellt. Durch phase cancellation Artefakte kann es bei der der Benutzung des Equine Distal Limb Scanner (Hallmarq Ldt.) schwierig sein, auf T2*-gewichteten Gradientenechosequenzen eine Sklerosierung des medullären Knochens von einer Flüssigkeitsansammlung zu unterscheiden (Werpy 2009). Verwendet man Gradientenechosequenzen mit einer Echozeit von 13, 39 oder 52 ms so löschen sich die Signale von Fett und Flüssigkeit, wenn sie in gleicher Menge vorliegen, gegenseitig aus und das Gewebe wird fälschlicher Weise signalarm (schwarz) dargestellt (Hood et al. 1999, Werpy 2009). Liegt mehr Flüssigkeit als Fettgewebe im medullären Knochen vor, stellt sich dieser Bereich wieder normal, also intermediär bis hyperintens dar (Werpy 2009, Olive et al. 2009). Kommt es zu einer Verletzung des medullären Knochens, liegen Fettgewebe und Flüssigkeit gleichzeitig in demselben Bereich vor, was die vorherigen Überlegungen für die richtige Interpretation von kernspintomographischen Befunden im Knochen wichtig machen.

STIR Sequenzen sind sehr sensitiv und spezifisch hinsichtlich der Detektion von Flüssigkeit im medullären Knochen (Werpy 2009, Olive et al. 2009, Holowinski et al. 2010). Diese Sequenzen sind aber sehr bewegungsanfällig und eine Detek- tion von Sklerosierungen des trabekullären Knochens ist hiermit nicht möglich. Wird das Fettsignal nicht optimal unterdrückt, werden Flüssigkeit und Fettgewebe gleich hyperintens dargestellt.

Anders als die T1- und T2-Gradientenechosequenzen zeigte die in dem vorliegenden Fall verwendete T2-gewichtete Spinechosequenz keine Veränderungen des medullären Knochens. Aufgrund der hohen Signalintensität von sowohl Fettgewebe als auch von Flüssigkeit ist eine Unterscheidung im kernspintomographischen Bild nicht möglich (Werpy 2009).

Im vorliegenden Fall zeigte die STIR-Sequenz in transversaler und sagittaler Ausrichtung ein hyperintenses Signal im dorsomedialen Bereich des medullären Knochens (Abb. 2). In den T2* GRE-Sequenzen ist, ebenfalls in allen Ausrichtungen, eine fokale Signalerniedrigung mit deutlich hypointensem Randbereich und zentraler Signalerhöhung im dorsomedialen Bereich des distalen Kronbeines zu erkennen (Abb. III). Eine Signalerniedrigung von geringerem Ausmaß ist an der beschriebenen Lokalisation auch in den TI GRE-Sequenzen nachvollziehbar (Abb. 4).

Zur Behandlung von knochenödem-ähnlichen Veränderungen liegen in der Pferdemedizin noch keine Studien vor. Faktoren, die eine prognostische Einschätzung solcher Erkrankungen möglich machen, sind noch nicht bekannt (Olive et al. 2009, Werpy 2009). Olive et al. (2009) vermuten, dass sich bei Pferden, die nicht innerhalb von drei bis vier Monaten auf die Therapie ansprechen, die Prognose hinsichtlich einer Lahmfreiheit deutlich verschlechtert. Ein Eckpfeiler der Therapie in der Humanmedizin scheint die die Ruhigstellung der betroffenen Gliedmaße zu sein. Die Daver und der Grad der Immobilisation richten sich nach dem Ausmaß der Veränderungen. Danach folgt eine Phase, während der die Patienten die Gliedmaße nicht voll belasten, was durch Rad fahren oder schwimmen erreicht wird. Medikamentös kann die Therapie zu Beginn der Erkrankung, insbesondere bei vorliegen einer schlechten Gliedmaßenfunktion, mit NSAIDs unterstütz† werden, wobei der potentiell osteoblastenhemmende Effekt dieser Therapeutika bedacht werden muss (Lassus et al. 2002). Nach Kenntnis der Autoren existieren keine Berichte zu der Anwendung von Bisphosphonaten bei dieser Indikation in der humanmedizinischen Literatur. Ein Knochenschmerz- lindernder Effekt ist aber beschrieben (Mannix et al. 2000). Inwiefern der osteoklastenhemmende Effekt der Bisphosphonate ursächlich für den Therapieerfolg im vorliegenden Fall war, kann abschließend nicht bewiesen werden. Da knochenödem-ähnliche Veränderungen aber durch eine gesteigerte Osteoklastenaktivität ausgelöst werden können, erscheint die Anwendung von Biphosphonaten durchaus sinnvoll. Janssen et al. (2012) behandelten lahme Pferde mit einer Signalerhöhung im Strahlbein mit Calciumdobesilat. Bei 11 von 12 Patienten konnte eine Verbesserung der Lahmheit gesehen werden. In den kernspintmographischen Nachuntersuchungen zeigte sich eine Reduktion des hyperintensen Signals im Strahlbein in den STIR-Sequenzen. Einen Zusammenhang zwischen der Behandlung mit Calciumdobesilat und einer Verbesserung der Lahmheit und einer Reduktion des MR-Signal im Strahlbein konnten die Autoren nicht darstellen. Ob eine chirurgische Intervention im Sinne einer Dekompression des intraosseären Drucks durch ein Anbohren des Knochens und eine Eröffnung der Corticalis eine therapeutische Option darstellt, kann im Moment noch 
nicht gesagt werden. Beschrieben ist dieser Ansatz bis jetzł nur für zwei Fälle von knochenödem-ähnlichen Veränderungen im Strahlbein. Nach der operativen Intervention zeigte sich eine klinische Verbesserung der Patienten (Murray 2011). In der Humanmedizin wird dieses chirurgische Verfahren hauptsächlich bei knochenödem-ähnlichen Veränderungen im Bereich des Femurkopfes mit Erfolg angewendet (Hofmann et al. 1993). Eine deutliche Verbesserung der Belastung bzw. Funktion der Gliedmaße konnte bei dem hier beschriebenen Patienten durch das Anlegen eines Robert-Jones Verbandes und die damit einhergehende Immobilisation erreicht werden. Weiterhin wäre eine weitere Entlastung der Gliedmaße durch eine Aufhängeeinrichtung wie z.B. dem Pferde Schwing-Lifter
(Michael Puhl GmbH) sinnvoll. Inwiefern und ob knochenödem-ähnliche Veränderungen eine Rolle bei degenerativen Gelenk- und Knochenerkrankungen eine Rolle spielen ist bist jetzt noch nicht bekannt. Kernspintomographische Untersuchungen an Pferden vor dem Beginn ihrer sportlichen Karriere und weitere Folgeuntersuchungen während ihrer sportlichen Nutzung sind wünschenswert, um eventuell bestehende Verbindungen zwischen und knochenödem-ähnlichen Veränderungen und degenerativen Gelenk- und Knochenerkrankungen an verschiedenen Lokalisationen darzustellen. In humanmedizinischen Studien konnte diese Verbindung schon an einer großen Anzahl von Probanden hergestellt werden (Zhao et al. 2010). 